\title{
Customers Perception towards Security and Privacy Issues of ATMs in Selected Public Sector Banks with Special Reference to Ramanathapuram District
}

\author{
${ }^{1}$ G. Athidass, ${ }^{2}$ Dr. K. Alamelu \\ ${ }^{1}$ Ph.D scholar, ${ }^{2}$ Professor, Department of Banking Management Alagappa University, Karaikudi, \\ Tamilnadu, India, ${ }^{1}$ dass.athiar@gmail.com, ${ }^{2}$ alakkn@gmail.com
}

Abstract - The ongoing advancements in Indian financial innovation have changed banking from the customary framework towards a progressively comprehensive one fusing the premiums of clients, the bank and nature. These days, banking tasks can be brought out through different financial conveyance channels from the bank offices. ATM is the most mainstream banking conveyance channel and the phenomenal achievement of ATMs had made the financial division fearless to grow increasingly imaginative elective conveyance channels such as Internet banking, mobile banking, Green channel counters, kiosk banking, credit card, debit card, online bill payment services etc. But in today's era of banking operation, identity theft, password protection is no longer adequate to guard your personal information. The paper mainly focuses on customers perception towards security and privacy issues of ATM'S in selected public sector banks with special reference to Ramanathapuram District. A Multi stage sampling method was used to select the banks and convenience sampling method has been adopted to select the respondents to collect data from 250 respondents by using a structured interview schedule. The result of the study shows that there may be deduction charges in ATMs is most influencing factor in security issues.

Key words: ATMs,CBS, E-Banking, Online Banking portals, Privacy, Security.

\section{INTRODUCTION}

A bank is money related foundation and monetary middle people that acknowledges stores and channelize them into loaning exercises, either legitimately or through capital markets. Afterward, customary financial framework was changed over in to e-banking. Prior to computerization of banks, the Ledger Posting Machines (ALPM) was utilized. To empower the e-banking framework, all bank offices were electronic and were presented 'any branch banking' and 'Center financial arrangement' (CBS). In India the main green bank is the State Bank of India(SBI), India's biggest business bank, which stepped up to the plate in setting high manageability benchmarks and finished the initial phase in "green banking" with shri O.P. Bhatt, director, SBI Inaugurate the bank's first wind ranch venture in Coimbatore. The green bank activity which incorporates ATMs, paperless banking for clients and working of wind processes in rustic India. Green Banking implies guaranteeing condition well disposed practices in banking segment and in this way lessening inside and outside carbon impressions.

It makes mechanical upgrades, operational enhancements and changing customer propensities in the financial area. The ongoing improvements in Indian financial innovation have changed banking from the conventional framework towards an increasingly comprehensive one joining the premiums of clients, the bank and nature. These days, banking activities can be brought out through different financial conveyance channels from the bank offices.ATM is the most mainstream banking conveyance channel and the remarkable achievement of ATMs had made the financial part gallant to grow increasingly inventive elective conveyance channels, for example, Internet banking, portable banking, Green channel counters, booth banking, charge card, plastic, online bill installment administrations and so forth.

ATMs (Automatic Teller Machines) were acquainted with the world in 1983. These advanced wonders of innovation were generally welcomed by purchasers since they made it workable for them to get to cash from their Master cards or check cards 24 hours out of every day with a speedy and straightforward framework. ATMs additionally made it feasible for buyers to movements in a more secure way they never again needed to convey a lot of money with them. Rather, they could get to cash anyplace on the planet with the assistance of the ATM. Despite the fact that ATMs made certain parts of life more secure, it made it simpler for forgers and cheats to exploit clueless customers. ATM implies not one or the other "abstains from going with cash" 
nor does "whenever cash" yet unquestionably suggest both. Thin ATM cards are quick supplanting puzzling withdrawal shapes as a helpful method for getting your cash from banks. As it were, they are modifying the standards of monetary exchange. Mechanized teller machines (ATMs) were the principal surely understood machines to give electronic access to client.

\section{REVIEW OF LITERATURE}

${ }^{1}$ Ranasinghe Arachchige Sudath Weerasiri (2017) in his paper is to comprehend the effect of ATM administration quality towards the consumer loyalty in Sri Lankan state banking segment. This exploration conquers any hindrance that exists in the present assemblage of information by examining the ATM administration characteristics and their effect on consumer loyalty. The information was gathered utilizing an organized survey intended to find out the fulfillment levels. Relapse, ANOVA and T-test were utilized to recognize noteworthy elements and recurrence examination was utilized to break down consumer loyalty. The ATM administration characteristics positively affect the consumer loyalty and the statistic factors like age and instructive capability moderate the connection between ATM administration quality and consumer loyalty. This paper distinguished the critical elements which the banks may take care to improve the consumer loyalty.

${ }^{2}$ Charles Swastika (2016) in his article says that Automated teller machine banking has become a critical channel for banking items and administrations behind branch banking in Malawi and banks keep on putting resources into new and productive advancements that can deal with more capacities that incorporate money saving to pull in more clients and accomplish consumer loyalty with the banks. Utilizing SPSS, relapse examination of fulfillment with Automated teller machine banking execution and fulfillment with the bank was led and the outcomes demonstrate that presentation of computerized teller machine banking has 40 percent prescient ability of consumer loyalty with the bank. The investigation further found that in spite of impacting consumer loyalty with the bank, Automated teller machine banking has no ability to draw in clients to switch banks. In this way banks could improve their consumer loyalty appraisals through upgrades in Automated teller machine banking administrations however where the banks wish to pull in clients from rivals, elective advertising methodologies ought to be looked for.

3 Akhtar, Raza, Siddiqi, Maqsood, Shouqat and Ijaz (2016) in his paper inspected that the reason for study recognizes the elements of ATM administration quality that impact the consumer loyalty. In banking segment information was gathered through poll with five point liker scale and test size 100 by utilizing accommodation inspecting system. SPSS 20 utilized as factual tests for the examination of relationship and relapse. Relapse examination found that positive and noteworthy outcome connection between value, unwavering quality, responsiveness, accommodation, security, administration quality on consumer loyalty. The administration of MCB bank should chip away at value, unwavering quality, and administration nature of ATM. In that review accommodation testing system was utilized for examining destinations since bank directors don't demonstrate readiness to share the individual data of their client because of security issues. Along these lines, the future research would be directed by utilizing irregular inspecting strategy for additional generalizability of results.

${ }^{4}$ Aida Fitrian (2018) in his paper found that the trust of utilizing robotized teller machine (ATM) is an overwhelming undertaking for some Indonesians, where the security issues related with, despite everything it frequenting them. The paper inspects the community oriented issues identified with the ATM security, for example, saw value and usability, and saw security, trust, goal to utilize and real framework use, by utilizing modified specialized acknowledgment model (TAM) as indicated by the financial purposes. The examination takes client tests of significant driving banks in Indonesia and expected to show the present circumstance looked by numerous Indonesians when managing the ATM security. The result will be significant contributions for the arrangement creators of the banks to set up further technique to adapt to incorporated security issues identified with ATM use.

\subsection{STATEMENT OF THE PROBLEM:}

In the development of technology, the bank has identified to introduce the electronic banking services. The e-banking services such as NEFT, RTGS, Online banking, Mobile banking and ATM. Among all other services the researcher focuses to study the customer perception towards security issues of ATMs. Most of the customers are using debit card. Majority of the people are using bank account in Ramanathapuram district and they are using debit card and they are facing many security issues due to ATMs. Therefore, it is important to make a study to gain insight about the customer satisfaction level with respect to various aspects of ATM services and security issues faced by customers in selected public sector banks of Ramanathapuram district.

\subsection{OBJECTIVE OF THE STUDY:}

$>$ To know the conceptual framework of Automated Teller Machine.

$>$ To analyze the customers perception towards security and issues of ATMs in selected public sector banks in Ramanathapuram District.

$>$ To offer suggestions' to overcome the security issues. 


\subsection{GROWTH OF ATMs:}

Table 1.1 ATMs of Scheduled Commercial Banks (As at end - March 2018)

\begin{tabular}{|l|l|l|l|l|l|l|}
\hline \multirow{2}{*}{ Bank Group } & \multicolumn{2}{|l|}{ On-site ATMs } & \multicolumn{2}{l|}{ Off-site ATMs } & \multicolumn{2}{l|}{$\begin{array}{l}\text { Total Number of } \\
\text { ATMs }\end{array}$} \\
\cline { 2 - 8 } & $\mathbf{2 0 1 7}$ & $\mathbf{2 0 1 8}$ & $\mathbf{2 0 1 7}$ & $\mathbf{2 0 1 8}$ & $\mathbf{2 0 1 7}$ & $\mathbf{2 0 1 8}$ \\
\hline $\begin{array}{l}\text { Public Sector } \\
\text { Banks }\end{array}$ & $\begin{array}{l}86,54 \\
5\end{array}$ & 82733 & 62,010 & 63235 & 148,555 & 145968 \\
\hline $\begin{array}{l}\text { Private Sector } \\
\text { Banks }\end{array}$ & $\begin{array}{l}23,04 \\
5\end{array}$ & 23829 & 35,788 & 36316 & 58,833 & 60145 \\
\hline Foreign Banks & 219 & 214 & 747 & 725 & 966 & 939 \\
\hline All SCBs & $\begin{array}{l}109,8 \\
09\end{array}$ & 106776 & 98,545 & 100276 & 208,354 & 207052 \\
\hline
\end{tabular}

(Source: RBI, Report on Trend and Progress of Banking in India, 2018)

From the above table 1.1, it is found that the total number of ATMs is 145968 , the total number of private sector banks ATMs is 60145 and foreign bank is 939.

\subsection{RESEARCH METHODOLOGY:}

\subsubsection{Research Design:}

The research carried out by the researcher is both descriptive and analytical in nature. This type of research is primarily concerned with explanation of facts. This study is called descriptive since it describes the Customers perception towards privacy and security issues of ATMs in selected public sector banks with special reference to Ramanathapuram District.

\subsubsection{Study unit of Research:}

The researcher selected Ramanathapuram district as study area.

\subsubsection{Population for the study:}

The present study was carried out with the objective to find out Customers perception towards privacy and security issues of ATMs in selected public sector banks with special reference to Ramanathapuram District. The researcher has selected the financial institutions, on the basis of the taluks which have higher number of bank branches in Ramanathapuram district. Regarding commercial banks, top five banks were selected namely SBI, Indian overseas bank, Indian Bank, Canara bank, and HDFC bank. The financial institutions were selected on the basis of those who provided more number of bank branches. In Ramanathapuram district, the sample bank branches were selected from Ramanathapuram and paramakudi taluks based on the number of branches.

Table No.1.2 List of bank branches in Ramanathapuram District

\begin{tabular}{|l|l|l|}
\hline BANK NAME & BRANCHES & TOTAL \\
\hline Indian Bank & 24 & \multirow{3}{*}{86} \\
\cline { 1 - 2 } Indian Overseas Bank & 23 & \\
\cline { 1 - 2 } State Bank of India & 20 & \\
\hline Canara Bank & 15 & \\
\cline { 1 - 2 } HDFC Bank & 4 & \\
\hline
\end{tabular}

(Sources: Primary data)

\subsubsection{Sample Size:}

The ultimate sample size for the study is 250 , which has been determined by the following formula.

\section{Sample Size Calculation:}

$\mathrm{n}=\left[\mathrm{Z}^{2} *(\mathrm{p} * \mathrm{q}) / \mathrm{d}^{2}\right]$

Where: $\mathrm{n}=\mathrm{s.s}$

$\mathrm{p}=$ expected precision

$\mathrm{q}=1-\mathrm{p}$ (expected non - precision)

$\mathrm{d}=$ relative desired precision

The total sample size for the study is 250 .

\subsection{Demographic Profile of Respondents:}

The researcher has discussed the profile of ATM cardholders like gender, age, educational qualification, occupation and family income by the respondents.

Table 1.3 Demographic Profile of the respondents

\begin{tabular}{|c|c|c|c|c|}
\hline \multirow{2}{*}{$\begin{array}{l}\text { S. } \\
\text { No }\end{array}$} & \multirow[t]{2}{*}{ Variable } & \multirow{2}{*}{$\begin{array}{c}\text { Classification } \\
\text { of Variable }\end{array}$} & Frequency & \multirow[t]{2}{*}{ Percentage } \\
\hline & & & $\mathrm{N}=70$ & \\
\hline \multirow[t]{2}{*}{1} & \multirow{2}{*}{ Gender } & Male & 28 & 56 \\
\hline & & Female & 22 & 44 \\
\hline \multirow[t]{3}{*}{2} & \multirow{3}{*}{ Age } & $18-22$ & 15 & 30 \\
\hline & & $23-28$ & 20 & 40 \\
\hline & & Above 29 & 15 & 30 \\
\hline \multirow[t]{3}{*}{2} & \multirow{3}{*}{$\begin{array}{l}\text { Educational } \\
\text { Qualification }\end{array}$} & Graduate & 10 & 10 \\
\hline & & Post Graduate & 20 & 40 \\
\hline & & Illiterate & 20 & 40 \\
\hline \multirow[t]{4}{*}{3} & \multirow[t]{4}{*}{ Occupation } & Student & 20 & 40 \\
\hline & & Govt Employee & 12 & 24 \\
\hline & & $\begin{array}{l}\text { Private } \\
\text { employee }\end{array}$ & 9 & 18 \\
\hline & & Self employee & 9 & 18 \\
\hline \multirow[t]{3}{*}{4} & \multirow{3}{*}{$\begin{array}{l}\text { Family } \\
\text { Income }\end{array}$} & Below 10000 & 39 & 78 \\
\hline & & $10000-40000$ & $\overline{9}$ & 18 \\
\hline & & Above 40000 & 2 & 4 \\
\hline
\end{tabular}

(Source: Primary data Software used: SPSS 23.0)

\subsubsection{Gender of the respondents:}

From the above table 1.2.1, it is understood that male $56 \%$ of the male respondents are using ATM card and $44 \%$ of them were female. Therefore, majority of them were male respondents were using ATM card holders.

\subsubsection{Age of the respondents:}

From the above table 1.2 .2 , it is understood that $30 \%$ of the respondents were fall in the age between $18-22,40 \%$ of them respondents were fall in the age between the $23-28,30 \%$ of them were fall in the age between above 29 years. Therefore, majority of them were 23-28 age were using ATM.

\subsubsection{Educational Qualification:}

From the above table 1.2 .3 , it is understood that $10 \%$ of the respondents were qualified graduate, $40 \%$ of the respondents were qualified post graduate and $40 \%$ of them were qualified Illiterate. Therefore, majority of them post graduate were using ATM card. 


\subsubsection{Occupation:}

From the above table 1.2 .3 , it is understood that $40 \%$ of the respondents were student, $24 \%$ of the respondents were Government employee and $18 \%$ of them were self employee. Therefore, majority of them were student.

\section{III.PERCEPTION TOWARD 'SECURITY AND PRIVACY CONCERN' REGARDING USE OF ATM:}

To measure bank customers' perception towards 'security and privacy concern' regarding use of ATMs, a self developed 8 items 'security and privacy concern: ATM' construct was used. Respondents were asked to indicate their opinion about given statements on Five point Likert Scale ranging from 'Strongly Agree' to 'Strongly Disagree'. The statements on different aspects of 'security and privacy concerns' were designed in such a way that agreeableness to a statement would reflect higher concern for a given aspect of security and privacy or vice verse. The level of security and privacy concern was measured by calculating Grand Mean. Descriptive and bank-wise respondents' perception towards security and privacy concern' regarding use of ATMs have been shown in table 1.4

Table 1.4 Security and Privacy concern regarding use of ATM

\begin{tabular}{|l|l|l|c|}
\hline \multicolumn{1}{|c|}{ Statement } & Mean & Rank & SD \\
\hline $\begin{array}{l}\text { There is a chance of my ATM } \\
\text { password being stolen }\end{array}$ & 1.58 & VI & .859 \\
\hline Possibility duplication of ATM card & 1.62 & V & .855 \\
\hline $\begin{array}{l}\text { Lower amount of cash may be } \\
\text { dispensed by the ATM }\end{array}$ & 4.28 & II & 1.089 \\
\hline $\begin{array}{l}\text { Withdrawal of cash by fraudulent } \\
\text { person without my ATM cards }\end{array}$ & 1.54 & VII & .813 \\
\hline $\begin{array}{l}\text { Transfer of cash fraudulent person } \\
\text { without my ATM cards }\end{array}$ & 3.90 & III & 1.111 \\
\hline $\begin{array}{l}\text { Deduction in the credit balance without } \\
\text { any transaction }\end{array}$ & 4.32 & I & .978 \\
\hline $\begin{array}{l}\text { Sharing of the card details by the bank } \\
\text { with other parties }\end{array}$ & 1.32 & VIII & .794 \\
\hline $\begin{array}{l}\text { Lack of privacy while using the } \\
\text { password }\end{array}$ & 1.96 & IV & 1.029 \\
\hline
\end{tabular}

Table 1.4 shows the mean score and the ranking security and privacy concern regarding use of ATM. Among nine statement enlisted in this study, there may be deduction in my balance without and transaction (4.32), consumers ATM may dispense less amount of currency than requested by me (4.28) and someone can transfer cash from my ATM without using my card (3.90) are the top three bank security and privacy concern regarding the purpose using of ATM. Therefore, it is concluded that the consumer perception towards security and privacy concern the main purpose of and reason for using ATM there may be deduction in consumer balance without any transaction.

\subsection{DIFFERENCE BETWEEN THE PERCEPTION TOWARD 'SECURITY AND PRIVACY CONCERN' REGARDING USE OF ATM - ANOVA:}

ATM is the most general banking delivery channel and the surprising success of ATMs had made the banking sector daring to develop more innovative substitute delivery channels such as Internet banking, mobile banking, Green channel counters, kiosk banking, credit card, debit card, online bill payment services etc. Occupation is most important in life of every human being. Bank customers are categorized into different occupation such as businessmen, self-employee and Government employee. Therefore to know the difference between occupation and customers' perception towards security issues of ATMs Anova were used. Anova is the specific tool to measure the significant difference or variance between the more than two groups in order to know the level of significant difference between occupation and customers' perception towards security issues of ATMs. The total variances are split up into has two components such as variation within a group and variation between a group.

Hypothesis: There is significant difference between occupation and customers' customers' perception towards security issues of ATMs

(Source: Primary data)

Table 1.5

Difference between occupation and customers' perception towards security issues of ATMs

\begin{tabular}{|c|c|c|c|c|c|}
\hline Statements & & Df & $\begin{array}{c}\text { Mean } \\
\text { square }\end{array}$ & $\mathbf{F}$ & Sig. \\
\hline \multirow{3}{*}{ There is a chance of my ATM password being stolen } & Between Groups & \multirow{3}{*}{$\begin{array}{l}1 \\
48 \\
49\end{array}$} & \multirow{3}{*}{$\begin{array}{l}2.808 \\
.695\end{array}$} & \multirow[t]{3}{*}{4.039} & \multirow[t]{3}{*}{.050} \\
\hline & Within Groups & & & & \\
\hline & Total & & & & \\
\hline \multirow{3}{*}{ Possibility duplication of ATM card } & Between Groups & \multirow{3}{*}{$\begin{array}{l}1 \\
48 \\
49\end{array}$} & \multirow{3}{*}{$\begin{array}{l}3.793 \\
.666\end{array}$} & \multirow[t]{3}{*}{5.692} & \multirow[t]{3}{*}{.021} \\
\hline & Within Groups & & & & \\
\hline & Total & & & & \\
\hline \multirow{3}{*}{ Lower amount of cash may be dispensed by the ATM } & Between Groups & \multirow{3}{*}{$\begin{array}{l}1 \\
48 \\
49\end{array}$} & \multirow{3}{*}{$\begin{array}{l}.042 \\
1.209\end{array}$} & \multirow[t]{3}{*}{.034} & \multirow[t]{3}{*}{.854} \\
\hline & Within Groups & & & & \\
\hline & Total & & & & \\
\hline \multirow{3}{*}{ Withdrawal of cash by fraudulent person without my ATM cards } & Between Groups & \multirow{3}{*}{$\begin{array}{l}1 \\
48\end{array}$} & \multirow{3}{*}{$\begin{array}{l}.000 \\
.675\end{array}$} & \multirow[t]{3}{*}{.000} & \multirow[t]{3}{*}{.989} \\
\hline & Within Groups & & & & \\
\hline & Total & & & & \\
\hline \multirow{2}{*}{ Transfer of cash fraudulent person without my ATM cards } & Between Groups & \multirow{2}{*}{$\begin{array}{l}1 \\
48\end{array}$} & \multirow{2}{*}{$\begin{array}{l}1.038 \\
1.239\end{array}$} & \multirow[t]{2}{*}{.838} & \multirow[t]{2}{*}{.364} \\
\hline & Within Groups & & & & \\
\hline
\end{tabular}




\begin{tabular}{|c|c|c|c|c|c|}
\hline & Total & & & & \\
\hline \multirow{3}{*}{ Deduction in the credit balance without any transaction } & Between Groups & \multirow{3}{*}{$\begin{array}{l}1 \\
48\end{array}$} & \multirow{3}{*}{$\begin{array}{l}.008 \\
.976\end{array}$} & \multirow[t]{3}{*}{.008} & \multirow[t]{3}{*}{.927} \\
\hline & Within Groups & & & & \\
\hline & Total & & & & \\
\hline \multirow{3}{*}{ Sharing of the card details by the bank with other parties } & Between Groups & \multirow{3}{*}{$\begin{array}{l}1 \\
48\end{array}$} & \multirow{3}{*}{$\begin{array}{l}4.726 \\
.545\end{array}$} & \multirow[t]{3}{*}{8.674} & \multirow[t]{3}{*}{.005} \\
\hline & Within Groups & & & & \\
\hline & Total & & & & \\
\hline \multirow{3}{*}{ Lack of privacy while using the password } & Between Groups & \multirow{3}{*}{$\begin{array}{l}1 \\
48\end{array}$} & \multirow{3}{*}{$\begin{array}{l}6.548 \\
.945\end{array}$} & \multirow[t]{3}{*}{6.928} & \multirow[t]{3}{*}{.011} \\
\hline & Within Groups & & & & \\
\hline & Total & & & & \\
\hline
\end{tabular}

(Source: Primary data)

From the above table it is inferred from ANOVA test the null hypothesis is rejected for all the variables because the $\mathrm{p}$ value is less than the bench mark value of 0.05 . Hence, it is concluded that the there is significant difference between occupation and customers perception towards security issues of ATMs such as ATM password may be stolen, ATM card may be cloned, ATM may dispense less amount of currency than requested by me, Someone may withdraw cash from my ATM without using the card, there may be deduction in the balance without any transaction, My card information may be shared by the bank with Third Party.

\section{IV.PERCEPTION TOWARD SECURITY AND PRIVACY SATISFACTION REGARDING USE OF ATM}

To measure bank customers' perception towards security and privacy satisfaction 'regarding use of ATM, a self developed 10 items 'Security and Privacy satisfaction: ATM' construct was used. Respondents were asked to indicate their opinion about given statements on Five point Likert Scale ranging from Strongly Agree' to Strongly Disagree'. The statements on different aspects of security and privacy satisfaction were designed in such a way that agreeableness to the statement would reflect the higher satisfaction for given aspect or vice versa. Further, mean scores have been calculated for each statement by assigning weights of 5,4,3,2 and 1 to strongly Agree', Agree', Neutral', Disagree 'and strongly Disagree'. The level of Security and Privacy satisfaction has been measured by taking the Grand Mean of all the statements'. Descriptive and bank- wise security and privacy satisfaction regarding ATM use have been shown in Table 1.6

Table: 1.6 Descriptive of security and Privacy satisfaction level regarding use of ATM

\begin{tabular}{|c|c|c|c|}
\hline Statement & Mean & Rank & SD \\
\hline ATM cash withdrawal are very safe & 4.48 & III & .814 \\
\hline My ATM PIN can never be hacked & 4.38 & IV & .830 \\
\hline My password is highly confidential others can't see while I using it & 4.26 & VI & 1.084 \\
\hline There is no possibility of duplication of my ATM cards & 4.34 & $\mathrm{~V}$ & .961 \\
\hline I get proper guidance of banks regarding security aspects of ATM transactions & 4.68 & I & .794 \\
\hline There are restrictions on more number of incorrect password usages & 4.22 & VII & 1.055 \\
\hline Faking of the card & 4.52 & II & .909 \\
\hline Security arrangements are proper in ATM cabin & 3.92 & IX & 1.368 \\
\hline A bank ensures privacy in the operation by ATMs & 4.16 & VIII & 1.184 \\
\hline Only one person is allowed to enter ATM cabin for transaction & 3.78 & $\mathrm{X}$ & 1.314 \\
\hline
\end{tabular}

(Source: Primary data)

Table 1.6 shows the mean score and the ranking descriptive of security and privacy satisfaction level regarding the consumer use of ATM. Among 10 statement enlisted in this study, consumers bank guidance about security tips from time to time (4.68), contact information is easily available to block ATM card (4.52) and It is safe to withdraw the cash from my banks' ATMs (4.48) are the top three reasons f/or consumer's getting level of satisfaction for using ATM card, similarly consumer's PIN can't be hacked while using my banks' ATMs (4.38), consumer's ATM card cannot be cloned (4.34) and it is not possible for other to see my password while entering (4.26) these are all the reasons also consumer having satisfaction with the using security and privacy of ATMs card. However the consumer having more satisfaction 
with the banks are giving more guidance about security tips from time to time.

1.9 Difference between Occupation and Perception toward Security and Privacy satisfaction regarding use of ATM ANOVA:

Hypothesis: There is significant difference between occupation and customers' satisfaction regarding use of ATM.

Table 1.7 ANOVA

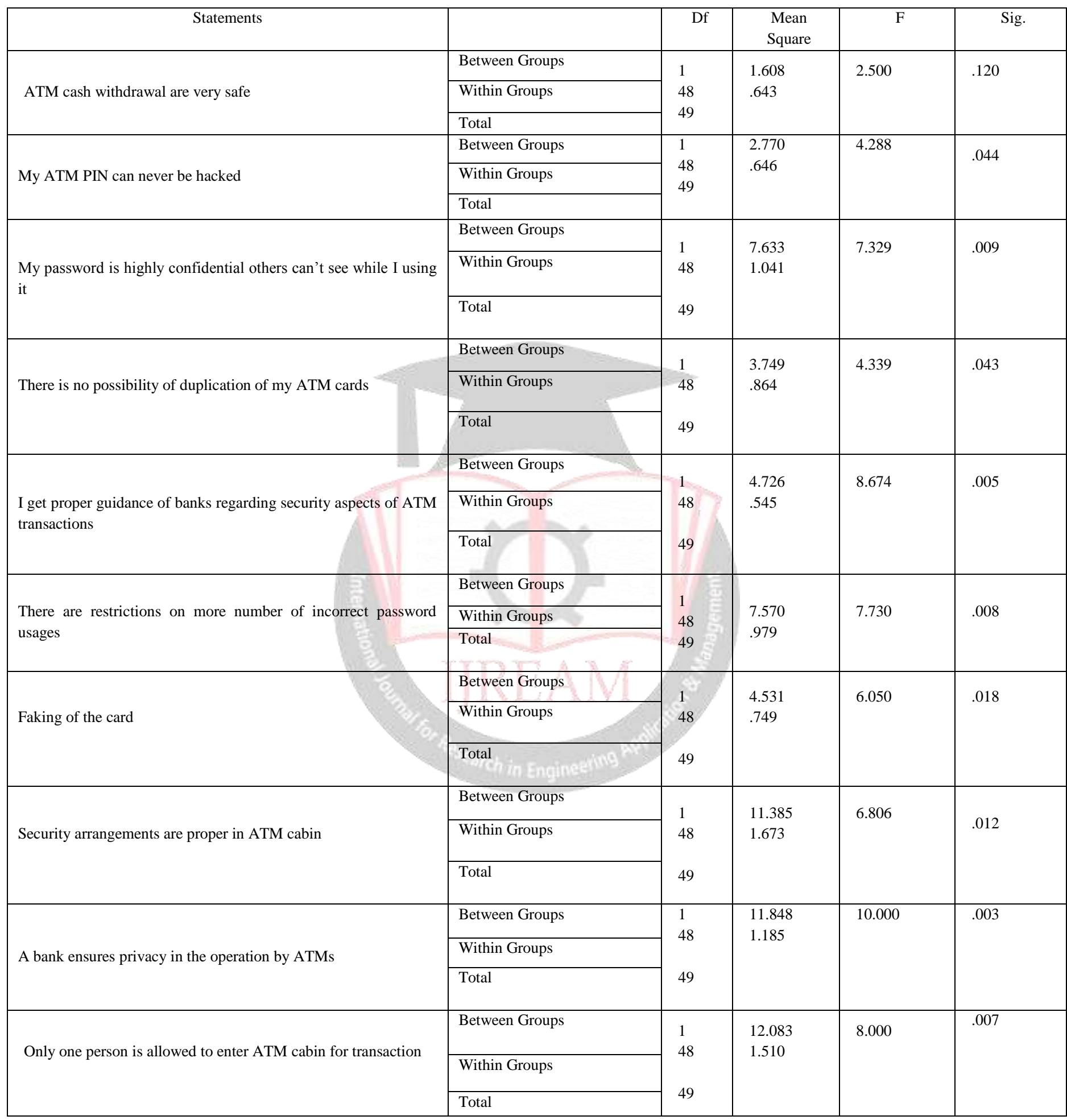

(Source: Primary data)

From the above table it is inferred from ANOVA test the null hypothesis is rejected for all the variables because the $\mathrm{p}$ value is less than the bench mark value of 0.05 . Hence, it is concluded that the there is significant difference between occupation and safe to withdraw the cash from my banks'
ATMs, PIN can't be hacked while using my banks' ATMs, it is not possible for other to see my password while entering, there is limit of maximum number of incorrect password submissions, there is adequate privacy while using ATM. 


\subsection{FINDINGS OF THE STUDY:}

$>$ It is understood that male $56 \%$ of the male respondents are using ATM card and $44 \%$ of them were female. Therefore, majority of them were male respondents were using ATM card holders.

$>$ It is found that $30 \%$ of the respondents were fall in the age between $18-22,40 \%$ of them respondents were fall in the age between the $23-28,30 \%$ of them were fall in the age between above 29 years. Therefore, majority of them were 23-28 age were using ATM.

$>$ It is found that $10 \%$ of the respondents were qualified graduate, $40 \%$ of the respondents were qualified post graduate and $40 \%$ of them were qualified Illiterate. Therefore, majority of them post graduate were using ATM card.

$>$ It is understood that $40 \%$ of the respondents were student, $24 \%$ of the respondents were Government employee and $18 \%$ of them were self employee. Therefore, majority of them were student.

$>\quad$ It is inferred from ANOVA test the null hypothesis is rejected for all the variables because the $p$ value is less than the bench mark value of 0.05 . Hence, it is concluded that the there is significant difference between occupation and customers perception towards security issues of ATMs such as ATM password may be stolen, ATM card may be cloned, ATM may dispense less amount of currency than requested by me, Someone may withdraw cash from my ATM without using the card, there may be deduction in the balance without any transaction,

$>$ Based on the result analysis, it is inferred from ANOVA test the null hypothesis is rejected for all the variables because the $p$ value is less than the bench mark value of 0.05 . Hence, it is concluded that the there is significant difference between occupation and safe to withdraw the cash from my banks' ATMs, PIN can't be hacked while using my banks' ATMs, it is not possible for other to see my password while entering, there is limit of maximum number of incorrect password submissions, there is adequate privacy while using ATM.

\section{CONCLUSION}

The Automated Teller Machine arrange for financial services to a growing segment of the population in several countries. Fingerprint scanning, continues to gain receipt as a reliable identification and verification processes. This paper is identifies a model for the alteration of existing Automated Teller Machine systems to economically incorporate fingerprint scanning PLUS blood group; and, frameworks the advantages of using such system. It must be noted that the customers 'perception cannot be comprehensive as it was highly affected by the convention or culture of the users includes.

\section{REFERENCES}

[1] Ranasinghe arachchige sudath weerasiri*; kosala chulani koththagoda (2017) "the impact of automated teller machines (atms) Service on customer satisfaction: a study based on State banks in Sri Lanka" south asian academic research journals Http://www.saarj.com issn: 2319-1422 vol 6, issue 2, march 2017 impact factor sjif $2013=2.380$.

[2] Charles Mwatsika (2016) "Impact of ATM Banking Performance on Customer Satisfaction with the Bank in Malawi”. International Journal of Business and Economics Research. Vol. 5, No. 1, 2016, pp. 1-9. doi: 10.11648/j.ijber.20160501.11, ISSN: 2328-7543 (Print); ISSN: 2328-756X (Online)

[3] Akhtar, Raza, Siddiqi, Maqsood, Shouqat \& Ijaz (2016) "Impact of A.T.M Service Quality on Customer Satisfaction: An Empirical Study in Kasur Pakistan Banking Sector" International Review of Management and Business Research Vol. 5 Issue.2, June 2016, ISSN: 2306-9007, pp 676-687

[4] Aida Fitriani*1, Sfenrianto2, "Examining the Security Issues of Automated Teller Machine Based on Revised Technical Acceptance Model" Available from: https://www.researchgate.net/publication/312203450_Examinin g_the_Security_Issues_of_Automated_Teller_Machine_Based_ on_Revised_Technical_Acceptance_Model [accessed Dec 23 2018] TELKOMNIKA, Vol.14, No.4, December 2016, pp. 1521 1526 ISSN: 1693-6930.

[5] Nana Kwame Gyamfi (2016) "Enhancing the Security Features of Automated Teller Machines (ATMs): A Ghanaian Perspective" International Journal of Applied Science and Technology Vol. 6, No. 1; February 2016.

[6] V.Rajendran (2018) "Banking on IT's Security" Chairman, Digital Security Association of India. The Journal of Indian Institute of Banking \& Finance, January - March 2018 pp13-18.

[7] S.Mukhopadhyay (2018) “A simple banker into Bank's Cyber security: understanding the task the role" The Journal of Indian Institute of Banking \& Finance ., January - March 2018 pp1926.

[8] Burra Butchi Babu(2018) "Cyber Security in Banks" The Journal of Indian Institute of Banking \& Finance, January March 2018 pp 27-32. 